\title{
Fly Ash as an Eco-Friendly Filler for Rigid Polyurethane Foams Modification
}

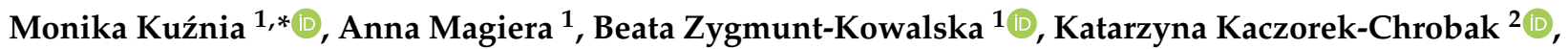 \\ Kinga Pielichowska ${ }^{3}$, Piotr Szatkowski ${ }^{3}{ }^{\circ}$, Aleksandra Benko ${ }^{3}{ }^{\circledR}$, Magdalena Ziąbka ${ }^{4}{ }^{-}$and Wojciech Jerzak ${ }^{1}$
}

1 Department of Heat Engineering and Environment Protection, Faculty of Metals Engineering and Industrial Computer Science, AGH University of Science and Technology, Mickiewicza 30 Av., 30-059 Krakow, Poland; asocha@agh.edu.pl (A.M.); zygmunt@agh.edu.pl (B.Z.-K.); wjerzak@agh.edu.pl (W.J.)

2 Instytut Techniki Budowlanej, Filtrowa 1, 00-611 Warszawa, Poland; k.kaczorek-chrobak@itb.pl

3 Department of Biomaterials and Composites, Faculty of Materials Science and Ceramics, AGH University of Science and Technology, Mickiewicza 30 Av., 30-059 Krakow, Poland; kingapie@agh.edu.pl (K.P.); pszatko@agh.edu.pl (P.S.); abenko@agh.edu.pl (A.B.)

4 Department of Ceramics and Refractories, Faculty of Materials Science and Ceramics, AGH University of Science and Technology, Mickiewicza 30 Av., 30-059 Krakow, Poland; ziabka@agh.edu.pl

* Correspondence: kuznia@agh.edu.pl

check for updates

Citation: Kuźnia, M.; Magiera, A.; Zygmunt-Kowalska, B.;

Kaczorek-Chrobak, K.; Pielichowska,

K.; Szatkowski, P.; Benko, A.; Ziąbka,

M.; Jerzak, W. Fly Ash as an

Eco-Friendly Filler for Rigid

Polyurethane Foams Modification.

Materials 2021, 14, 6604. https://

doi.org/10.3390/ma14216604

Academic Editor: Kamila Sałasińska

Received: 9 October 2021

Accepted: 28 October 2021

Published: 2 November 2021

Publisher's Note: MDPI stays neutral with regard to jurisdictional claims in published maps and institutional affiliations.

Copyright: (C) 2021 by the authors. Licensee MDPI, Basel, Switzerland. This article is an open access article distributed under the terms and conditions of the Creative Commons Attribution (CC BY) license (https:// creativecommons.org/licenses/by/ $4.0 /)$.

\begin{abstract}
There is currently a growing demand for more effective thermal insulation materials with the best performance properties. This research paper presents the investigation results on the influence of two types of filler on the structure and properties of rigid polyurethane foam composites. Fly ash as a product of coal combustion in power plants and microspheres of 5, 10, 15 , and $20 \mathrm{wt} . \%$, were used as rigid polyurethane foams modifiers. The results of thermal analysis, mechanical properties testing, and cellular structure investigation performed for polyurethane composites show that the addition of fly ash, up to $10 \mathrm{wt}$ \%, significantly improved the majority of the tested parameters. The use of up to $20 \mathrm{wt} . \%$ of microspheres improves the mechanical and thermal properties and thermal stability of rigid polyurethane foams.
\end{abstract}

Keywords: composite materials; eco-friendly fillers; fly ash; microspheres; rigid polyurethane foams

\section{Introduction}

One of the most popular and commonly used thermosetting polymeric materials is rigid polyurethane (PUR) foam [1]. Due to its low thermal conductivity, it is mainly used in the building and construction industry [2]. Moreover, its good performance properties, i.e., low apparent density $\left(25-50 \mathrm{~kg} / \mathrm{m}^{3}\right)$ [3], chemical resistance, good thermal and mechanical characteristics $[4,5]$, resulted in the more widespread usage of PUR in other industries, including automotive, furniture for public transportation, astronautics, refrigerators and petrochemical engineering [6-8].

Since markets' demands for PUR is considerable, growth in production of this material is observed every year. According to the Global Rigid Polyurethane Foam Sales Market Report 2021, published by Industry Research, the global market of this type of materials was valued at USD 6979 in 2020 and will reach USD 10,410 million by the end of 2027 [9]. The vast interest in thermal insulating materials, in particular PUR foam, mobilized researchers to seek new solutions when producing PUR materials. Two of the most recognizable motives are the willingness to reduce production costs and the tendency to eliminate petrochemical products from the environment. The introduction of the fillers can modify PUR during the production process. Numerous studies focused on the filler addition effect on the physical properties of PUR foams, such as density, thermal and mechanical properties, polyurethane cell structure and flame retardancy [10-17]. Kuźnia et al. [18] modified PUR foam with fluidized bed combustion fly ash, a waste material rarely used in the industry. With up to $20 \mathrm{wt}$ \% of the filler, foam showed improved thermal stability, 
reduced carbon contents, and gross calorific values. Choe et al. [19] used chemically treated $\mathrm{CaCO}_{3}$ fillers to improve the acoustics and mechanical properties of the foams. The research obtained composite materials with lower porosity and higher compressive strength than not chemically modified fillers.

In this study, PUR composite was prepared using two types of fillers: fly ash (FA) from a pulverized bituminous coal-fired boiler and microspheres (M), which were the separated fraction of FA. FA generated in pulverized boilers was used as source material in geopolymers [20,21] and concrete [22], as well as thermal properties' modifier in polymer composites [23-25] and flame-retardant in low-density polyethene [26]. M represent valued performance properties, including low density, thermal and mechanical stability, hydrophobicity. They were used as a component of insulating and non-flammable materials, composites and light concrete [23,26-30]. Thus, FA and M consist of a cheap, potential filler and flame-retardant in PUR production.

Furthermore, both species are waste materials and using them in the PUR formulation process can diametrically can significantly reduce the negative impact on the environment resulting from their storage. The authors attempt to describe the influence of the aforementioned fillers and their concentration on PUR physical and performance properties. PUR composite characteristics, which were under investigation, were: polyurethane cellular structure, chemical structure, mechanical properties, thermal properties and thermal stability. The most frequently studied fillers used in PUR materials are mainly flame-retardant additives. There are a few publications that related to the use of FA and M in the PUR modifications $[18,31,32]$. Therefore, the research topic discussed in this article is innovative and there are no published research results in this field.

The addition of $\mathrm{M}$ and FA to other polymeric materials is used in polymer chemistry, i.e., FA-reinforced thermoplastic starch composites [33] or other polymer composites reinforced with FA [34-36]. The most frequently studied fillers used in PUR materials are mainly flame-retardant additives. There are a few publications that related to the use of industrial waste in the PUR modifications. Therefore, the research topic discussed in this article is innovative and there are no published research results in this field. The latest research has shown that FA might express high levels of toxicity on human health [37]. The research was assessed in vitro using HeLa cells and Jurkat cells. The size of ash particles appeared to be an important determinant of their toxicity. Authors realize that further research is needed to evaluate the toxicity of polyurethane materials doped with FA prior to practical used.

\section{Materials and Methods}

\subsection{Characterization of the Fly Ash and Microsphere}

FA, obtained from one of the Polish power plants and generated in a pulverized bituminous coal-fired boiler, and M, acquired from one of Kazakh coal-fuelled power plant and separated from FA by flotation method in were taken for an investigation. Kazakhstan's $\mathrm{M}$ are characterized by a larger grain diameter and a higher $\mathrm{Al}_{2} \mathrm{O}_{3}$ content compared to Polish. FA and $\mathrm{M}$ were used for formulation in unmodified form. Scanning electron microscope (SEM) images (Figure 1) illustrate the shape of FA, and M. FA particles were rounded, and coarse, sparse M could be detected. 


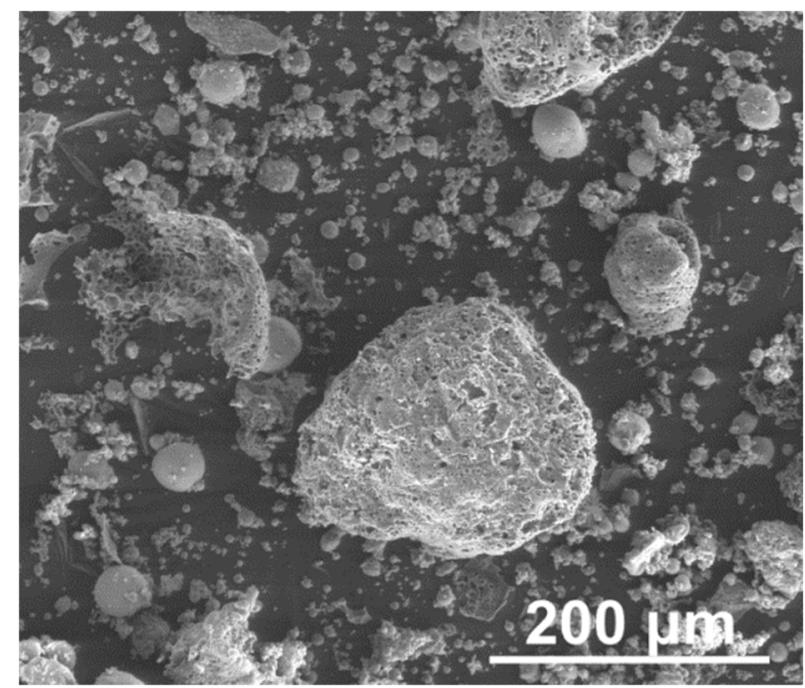

(a)

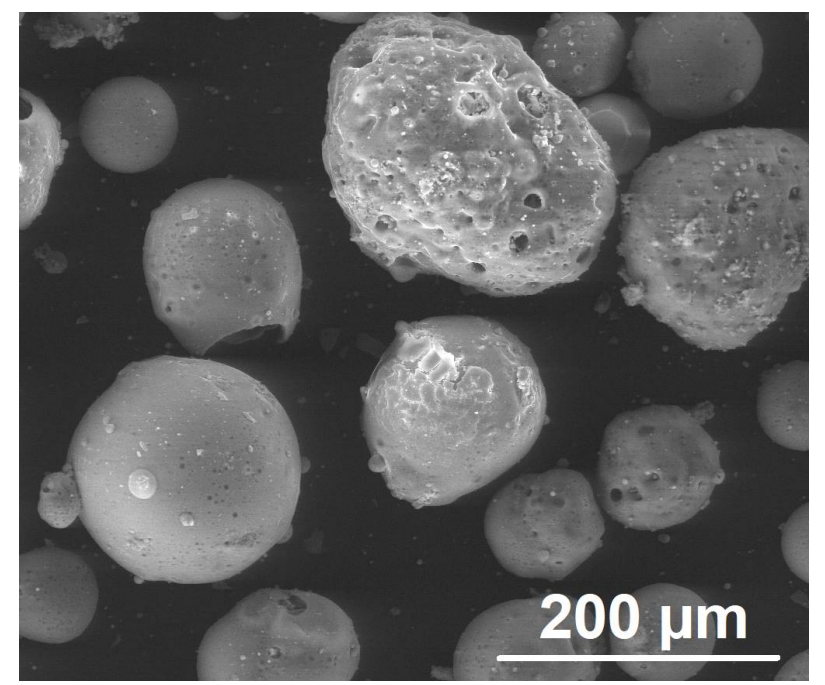

(b)

Figure 1. SEM images of FA (a) and M (b). Magnitudes $\times 350$.

In most cases, $\mathrm{M}$ constituted about $1-2 \%$ of FA obtained from coal combustion. $\mathrm{M}$ are filled with exhaust gases, which are present in the coal boiler; mainly with $\mathrm{CO}_{2}$ and $\mathrm{N}_{2}$. They consist of a spherical structure. The diameter of grains was smaller than $200 \mu \mathrm{m}$, while in most cases, their dimensions ranged from 1 to $150 \mu \mathrm{m}$ (Figure 2a), and the shell thickness was several micrometers (Figure 2b). M were mainly cenospheres, and their surface was coarse.

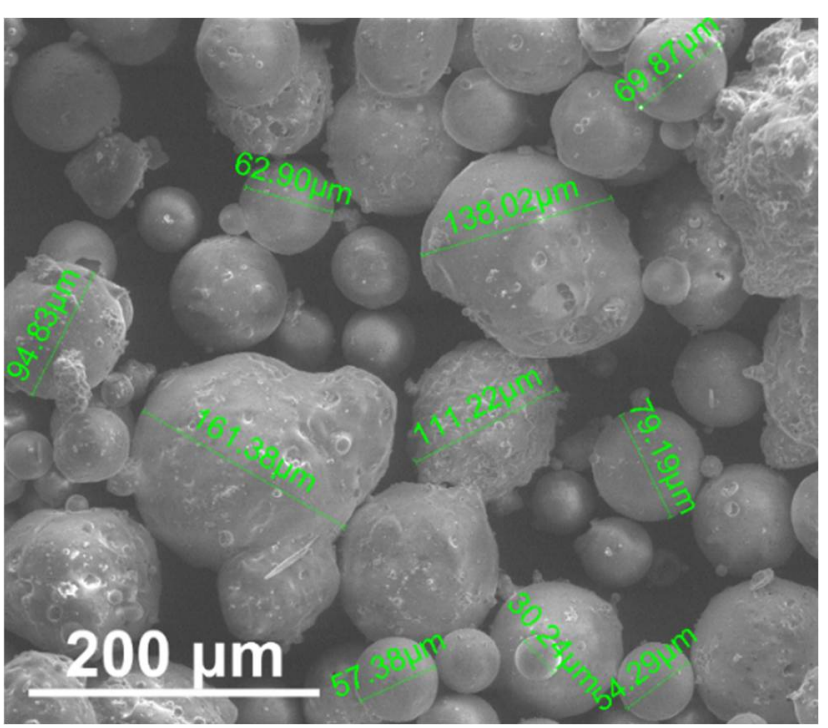

(a)

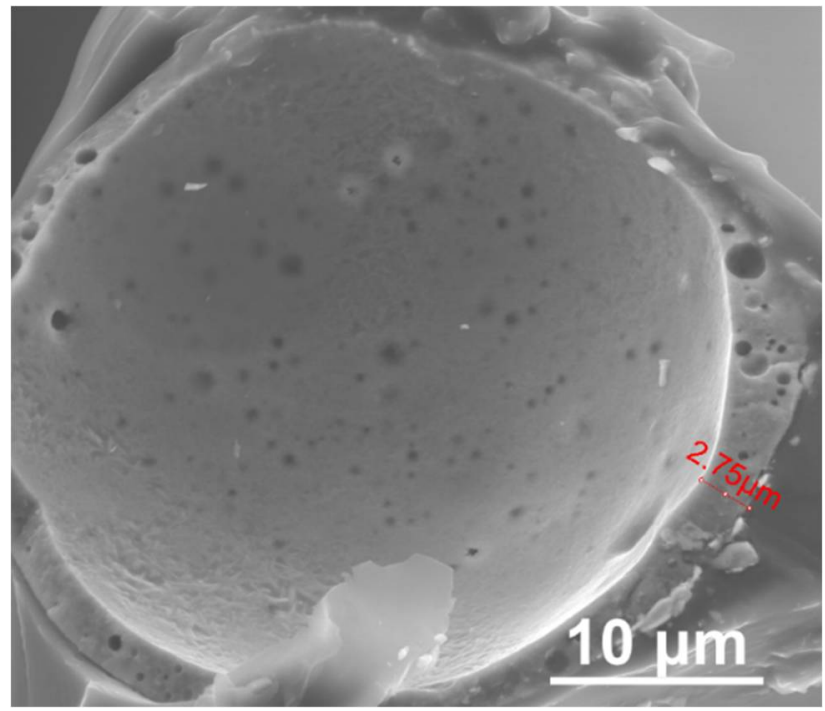

(b)

Figure 2. SEM images of different sizes of $M(\mathbf{a})$ and broken $M(\mathbf{b})$. Magnitudes $\times 350(\mathbf{a})$, and $\times 5000(\mathbf{b})$.

In the primary stage of this research, FA and M composition and morphology were characterized. The detailed results of these studies were published elsewhere [30,31]. The median particle size (D50) of FA, measured by the particle size analyzer (Malvern Mastersizer 2000 Ver. 5.60; Malvern Instruments Ltd., Malvern, UK), was $159 \mu \mathrm{m}$. The chemical composition was analyzed by an X-ray fluorescence (XRF) spectrometer. Chemical composition of FA and $\mathrm{M}$ is shown in Table 1. FA has been found to consist of $\mathrm{SiO}_{2}(52.3 \%)$, $\mathrm{Al}_{2} \mathrm{O}_{3}(27.4 \%), \mathrm{Fe}_{2} \mathrm{O}_{3}(7.9 \%), \mathrm{K}_{2} \mathrm{O}(4.2 \%), \mathrm{CaO}(3.0 \%), \mathrm{TiO}_{2}(1.4 \%)$, and $\mathrm{SO}_{3}(1.2 \%)$. Mineral phases, identified and quantified using the $\mathrm{X}$-ray diffraction $(\mathrm{XRD})$ method, were mullite 
and quartz. The physical density of FA was $2.15 \mathrm{~g} / \mathrm{cm}^{3}$. The median particle size (D50) of $\mathrm{M}$ was $158 \mu \mathrm{m}$. M were composed of $\mathrm{SiO}_{2}(52.8 \%), \mathrm{Al}_{2} \mathrm{O}_{3}(39.9 \%), \mathrm{CaO}(1.4 \%), \mathrm{Fe}_{2} \mathrm{O}_{3}$ $(1.4 \%), \mathrm{TiO}_{2}(1.2 \%)$ and $\mathrm{P}_{2} \mathrm{O}_{5}(1.0 \%)$. M was mainly amorphous, and mineral phases of mullite, corundum and quartz were detected. Physical density was $0.39 \mathrm{~g} / \mathrm{cm}^{3}$.

Table 1. Chemical composition of flay ash and microspheres.

\begin{tabular}{|c|c|c|c|c|c|c|c|}
\hline \multicolumn{4}{|c|}{ Fly Ash } & \multicolumn{4}{|c|}{ Microspheres } \\
\hline Element & Conc., \% & Oxide & Conc., \% & Element & Conc., \% & Oxide & Conc., $\%$ \\
\hline $\mathrm{Mg}$ & 0.658 & $\mathrm{MgO}$ & 1.464 & $\mathrm{O}$ & 49.30 & $\mathrm{Na}_{2} \mathrm{O}$ & 0.464 \\
\hline $\mathrm{Al}$ & 18.10 & $\mathrm{Al}_{2} \mathrm{O}_{3}$ & 27.38 & $\mathrm{Si}$ & 24.69 & $\mathrm{MgO}$ & 0.274 \\
\hline Si & 35.53 & $\mathrm{SiO}_{2}$ & 52.31 & $\mathrm{Al}$ & 21.12 & $\mathrm{Al}_{2} \mathrm{O}_{3}$ & 39.91 \\
\hline $\mathrm{P}$ & 0.748 & $\mathrm{P}_{2} \mathrm{O}_{5}$ & 0.880 & $\mathrm{Ca}$ & 1.016 & $\mathrm{SiO}_{2}$ & 52.83 \\
\hline$S$ & 1.035 & $\mathrm{SO}_{3}$ & 1.201 & $\mathrm{Fe}$ & 0.984 & $\mathrm{P}_{2} \mathrm{O}_{5}$ & 1.017 \\
\hline $\mathrm{K}$ & 9.383 & $\mathrm{Cl}$ & 0.000 & $\mathrm{Ti}$ & 0.728 & $\mathrm{SO}_{3}$ & 0.032 \\
\hline $\mathrm{Ca}$ & 6.434 & $\mathrm{~K}_{2} \mathrm{O}$ & 4.153 & $\mathrm{P}$ & 0.443 & $\mathrm{~K} 2 \mathrm{O}$ & 0.502 \\
\hline $\mathrm{Ti}$ & 2.819 & $\mathrm{CaO}$ & 2.954 & $\mathrm{~K}$ & 0.416 & $\mathrm{CaO}$ & 1.421 \\
\hline $\mathrm{V}$ & 0.115 & $\mathrm{TiO}_{2}$ & 1.409 & $\mathrm{Na}$ & 0.344 & $\mathrm{TiO}_{2}$ & 1.215 \\
\hline $\mathrm{Cr}$ & 0.076 & $\mathrm{~V}_{2} \mathrm{O}_{5}$ & 0.058 & As & 0.246 & $\mathrm{Cr}_{2} \mathrm{O}_{3}$ & 0.006 \\
\hline $\mathrm{Mn}$ & 0.224 & $\mathrm{Cr}_{2} \mathrm{O}_{3}$ & 0.033 & $\mathrm{Ba}$ & 0.237 & $\mathrm{MnO}$ & 0.033 \\
\hline $\mathrm{Fe}$ & 21.29 & $\mathrm{MnO}$ & 0.078 & $\mathrm{Mg}$ & 0.165 & $\mathrm{Fe}_{2} \mathrm{O}_{3}$ & 1.407 \\
\hline Co & 0.094 & $\mathrm{Fe}_{2} \mathrm{O}_{3}$ & 7.916 & $\mathrm{Sr}$ & 0.101 & $\mathrm{CuO}$ & 0.010 \\
\hline $\mathrm{Ni}$ & 0.058 & $\mathrm{Co}_{3} \mathrm{O}_{4}$ & 0.030 & $\mathrm{~F}$ & 0.076 & $\mathrm{ZnO}$ & 0.004 \\
\hline $\mathrm{Cu}$ & 0.042 & $\mathrm{NiO}$ & 0.015 & $\mathrm{Zr}$ & 0.032 & $\mathrm{Ga}_{2} \mathrm{O}_{3}$ & 0.005 \\
\hline $\mathrm{Zn}$ & 0.083 & $\mathrm{CuO}$ & 0.011 & $\mathrm{Cl}$ & 0.029 & $\mathrm{As}_{2} \mathrm{O}_{3}$ & 0.325 \\
\hline $\mathrm{Ga}$ & 0.011 & $\mathrm{ZnO}$ & 0.022 & Mn & 0.026 & $\mathrm{Rb}_{2} \mathrm{O}$ & 0.002 \\
\hline As & 0.004 & $\mathrm{Ga}_{2} \mathrm{O}_{3}$ & 0.003 & $S$ & 0.013 & $\mathrm{SrO}$ & 0.119 \\
\hline $\mathrm{Br}$ & 0.004 & $\mathrm{GeO}_{2}$ & 0.000 & $\mathrm{Cu}$ & 0.008 & $\mathrm{Y}_{2} \mathrm{O}_{3}$ & 0.006 \\
\hline $\mathrm{Rb}$ & 0.035 & $\mathrm{Br}$ & 0.001 & $\mathrm{Y}$ & 0.005 & $\mathrm{ZrO}_{2}$ & 0.044 \\
\hline $\mathrm{Sr}$ & 0.074 & $\mathrm{Rb}_{2} \mathrm{O}$ & 0.008 & $\mathrm{Cr}$ & 0.004 & $\mathrm{BaO}$ & 0.264 \\
\hline $\mathrm{Y}$ & 0.006 & $\mathrm{SrO}$ & 0.018 & $\mathrm{Ga}$ & 0.003 & $\mathrm{PbO}$ & 0.002 \\
\hline $\mathrm{Zr}$ & 0.032 & $\mathrm{Y}_{2} \mathrm{O}_{3}$ & 0.002 & $\mathrm{Zn}$ & 0.003 & $\mathrm{~F}$ & 0.076 \\
\hline $\mathrm{Ag}$ & 0.065 & $\mathrm{ZrO}_{2}$ & 0.009 & $\mathrm{~Pb}$ & 0.002 & $\mathrm{Cl}$ & 0.030 \\
\hline Sn & 0.003 & $\mathrm{Nb}_{2} \mathrm{O}_{5}$ & 0.001 & $\mathrm{Rb}$ & 0.002 & - & - \\
\hline $\mathrm{Ba}$ & 0.021 & $\mathrm{Ag}_{2} \mathrm{O}$ & 0.015 & - & - & - & - \\
\hline $\mathrm{Pb}$ & 0.043 & $\mathrm{SnO}_{2}$ & 0.001 & - & - & - & - \\
\hline - & - & $\mathrm{BaO}$ & 0.006 & - & - & - & - \\
\hline - & - & $\mathrm{HgO}$ & 0.009 & - & - & - & - \\
\hline - & - & $\mathrm{As}_{2} \mathrm{O}_{3}$ & 0.001 & - & - & - & - \\
\hline
\end{tabular}

\subsection{PUR Foams Formulation}

Polyurethane (PUR) rigid foams were prepared using the two-component commercial system EKOPRODUR PM4032 (PCC Rokita S.A., Brzeg Dolny, Poland). Both components, polyol and isocyanate (weight ratio 100:120), were mixed using a mechanical stirrer (4500 rpm for $1 \mathrm{~min}$ ) and cast into rectangular mold dimensions of $20 \times 20 \times 5 \mathrm{~cm}$, then left under a fume hood for the polymerization reaction to terminate. After $48 \mathrm{~h}$ of setting, foams were removed from the molds and left under the fume hood for a further 5 days (to eliminate the unreacted isocyanate component). At the first stage of formulation, the proportionate amounts $(5,10,15$, and $20 \mathrm{wt} . \%)$ of the filler (FA or M) were added to the polyol component and then mixed with isocyanate. The composite foam samples were labelled as PUR + FA5, PUR + FA10, PUR + FA15, PUR + FA20, PUR + M5, PUR + M10, PUR + M15 and PUR + M20.

\subsection{PUR Foams Characteristics}

The morphology of the cellular PUR structure was analyzed using the optical microscope Keyence VHX-900F (Keyence, Osaka, Japan). PUR foam samples were prepared by cutting into regular cuboids with dimensions $5 \times 5 \times 0.5 \mathrm{~cm}$. Optical microphotographs were registered from different areas of each sample. Images were analyzed using the 
ImageJ (version 1.48v) free software. Horizontal and vertical Feret diameters characterizing the cellular PUR matrix structure were measured. Average values of diameters, together with standard deviations, were calculated from 50-60 counts. Other parameters measured were strut thickness (average and SD values of 50-60 counts) and a closed cells' per cent. Additional observations were performed using the scanning electron microscope, SEM (Nova NanoSEM 200; FEI Company, Hillsboro, Oregon, USA). The cubic samples with dimensions $0.5 \times 0.5 \times 0.5 \mathrm{~cm}$, then coated with gold and observed with the acceleration of $10 \mathrm{kV}$.

Fourier-transform infrared (FTIR) spectroscopy was used to define the molecular structure of foams. IR spectra were registered on Tensor 27 spectrometer (Bruker Optics, Billerica, Massachusetts, USA), operating with OPUS 7.2 software. Spectra were collected in the mid region of $4000-400 \mathrm{~cm}^{-1}$ after 64 scans at $4 \mathrm{~cm}^{-1}$ resolution in absorbance mode using the $\mathrm{KBr}$ pellet method. Materials analyzed were PUR foam, powdered FA and $\mathrm{M}$, and composite foams PUR + FA20 and PUR + M20 (other composites were not included in testing due to low filler content).

Mechanical testing of the materials was performed on the universal testing machine Zwick 1435 (Zwick Roell, Ulm, Germany; load cell $5 \mathrm{kN}$ ). Foam samples were prepared in the form of cylinders, with diameters of $30 \mathrm{~mm}$ and to heights of $12 \mathrm{~mm}$ and compressed at a speed of $2 \mathrm{~mm} / \mathrm{min}$ until $75 \%$ deformation. Compressive strength $\left(R_{\mathrm{s}}\right)$ and Young's modulus (E), were calculated from the obtained stress-strain curves. For each type of material, the results of the measurements were summarized as the average of six tests and the standard deviation (SD) value.

Thermal analysis was conducted using differential scanning calorimeter (DSC), Mettler Toledo DSC1 (Mettler Toledo, Switzerland) in the inert atmosphere of nitrogen. The 3-4 mg were closed in pierced aluminum pans and measured (heated/cooled) at the rate of $10^{\circ}$ samples $\mathrm{C} / \mathrm{min}$ in the range of $-50-240^{\circ} \mathrm{C}$. Thermogravimetric analysis (TGA) was also carried out using Discovery TGA 550 instrument (TA Instruments, New Castle, DE, USA). The 5-6 mg samples were tested in platinum pans in the nitrogen atmosphere in the range of temperatures $45-700{ }^{\circ} \mathrm{C}$ at the heating rate of $10{ }^{\circ} \mathrm{C} / \mathrm{min}$.

\section{Results and Discussion}

\subsection{Cellular Structure}

The reference unmodified PUR foam was also taken for investigation under the optical microphotograph (Figure 3a). The well-formed cellular structure can be seen on the crosssection of a reference sample. The observed cells were polyhedron in shape, uniform (SD values were small and did not exceed $8 \%$ of the average values), most of them were closed, which is an important characteristic influencing thermal insulation properties of the PUR foams $[32,38,39]$. 


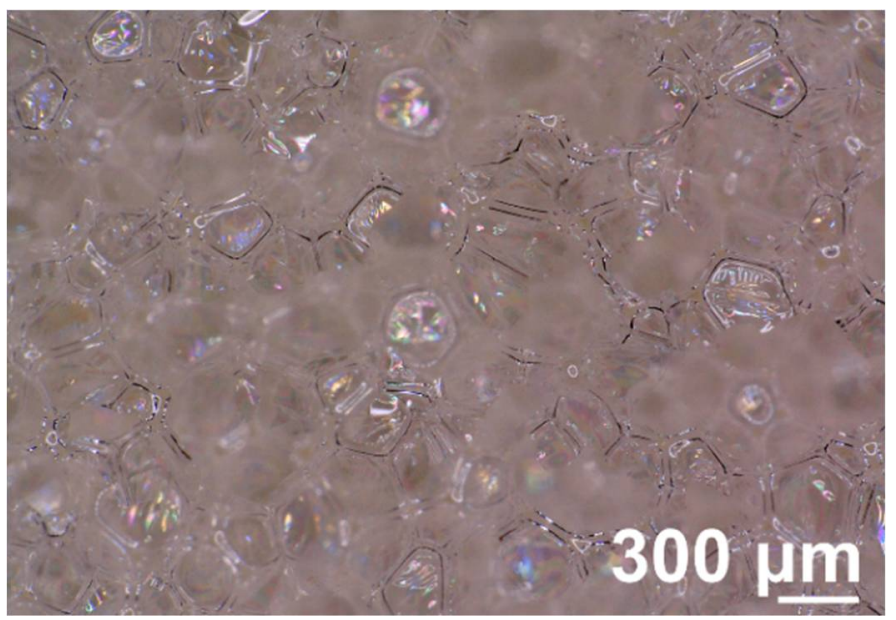

(a)

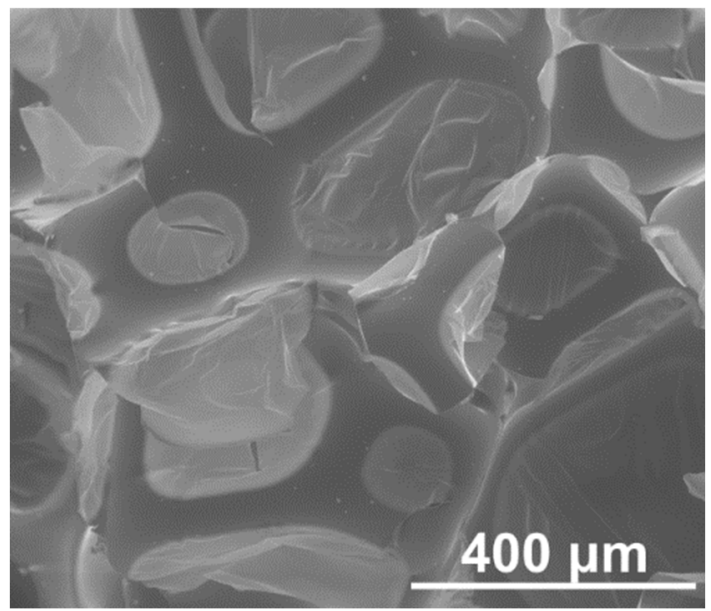

(b)

Figure 3. Optical (a) and SEM image (b) of the cross-sections of PUR foam. Magnitudes $\times 100(\mathbf{a})$, and $\times 200(\mathbf{b})$.

Strut thickness (Table 2) of the cells was approximately $20 \mu \mathrm{m}$, vertical and horizontal Feret diameters were 193 and $207 \mu \mathrm{m}$. The similarity in both Feret diameters values indicated no favorable growth direction within the cross-sectional area of the sample. SEM image (Figure 3b) shows minor disruption of the cellular structure caused by the coating with the gold process.

Table 2. PUR cellular morphology parameters.

\begin{tabular}{ccccc}
\hline Sample Name & $\begin{array}{c}\text { Vertical Feret } \\
\text { Diameter, } \boldsymbol{\mu m}\end{array}$ & $\begin{array}{c}\text { Horizontal Feret } \\
\text { Diameter, } \boldsymbol{\mu m}\end{array}$ & $\begin{array}{c}\text { Strut Thickness, } \\
\boldsymbol{\mu m}\end{array}$ & $\begin{array}{c}\text { Closed } \\
\text { Cells' }^{\prime} \\
\text { Content, \% }\end{array}$ \\
\hline PUR & $193 \pm 15$ & $207 \pm 16$ & $20 \pm 1$ & 88 \\
PUR + FA5p & $150 \pm 6$ & $156 \pm 7$ & $17 \pm 1$ & 82 \\
PUR + FA10p & $138 \pm 8$ & $147 \pm 8$ & $19 \pm 1$ & 77 \\
PUR + FA15p & $170 \pm 12$ & $148 \pm 11$ & $22 \pm 1$ & 78 \\
PUR + FA20p & $181 \pm 11$ & $170 \pm 10$ & $22 \pm 1$ & 78 \\
PUR + M5p & $154 \pm 8$ & $149 \pm 7$ & $20 \pm 1$ & 83 \\
PUR + M10p & $169 \pm 12$ & $173 \pm 11$ & $21 \pm 1$ & 77 \\
PUR + M15p & $196 \pm 18$ & $192 \pm 20$ & $20 \pm 1$ & 70 \\
PUR + M20p & $152 \pm 11$ & $158 \pm 9$ & $20 \pm 1$ & 76 \\
\hline
\end{tabular}

SEM images of the cross-sections of PUR foams modified with FA and M are given in Figure 4. The performed analysis pointed out that the addition of both types of filler did not disrupt the cellular structure of the PUR matrix; however, a decrease in closed cells' content was observed, reaching approx. $84 \%$. 


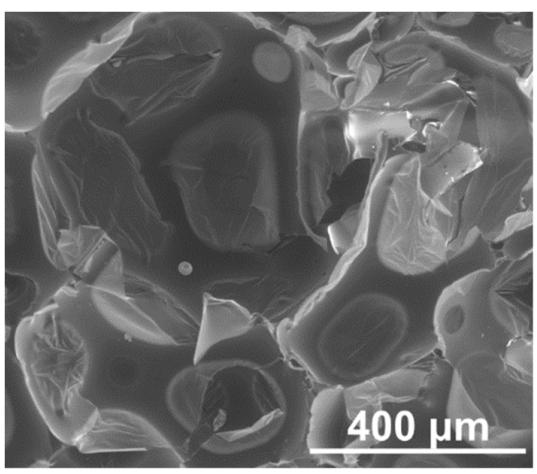

(a)

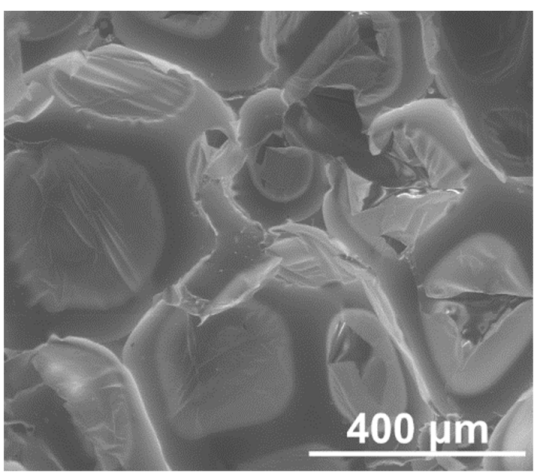

(c)

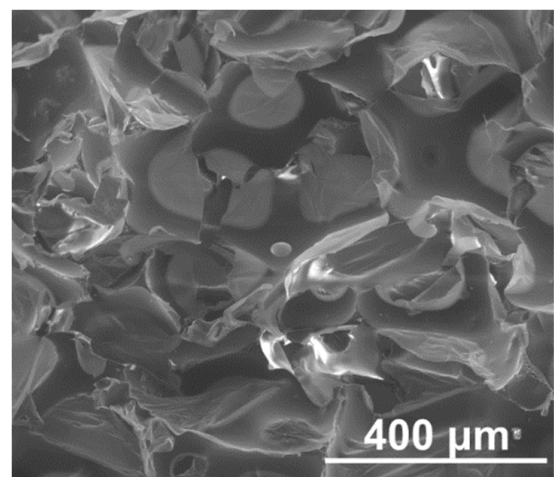

(e)

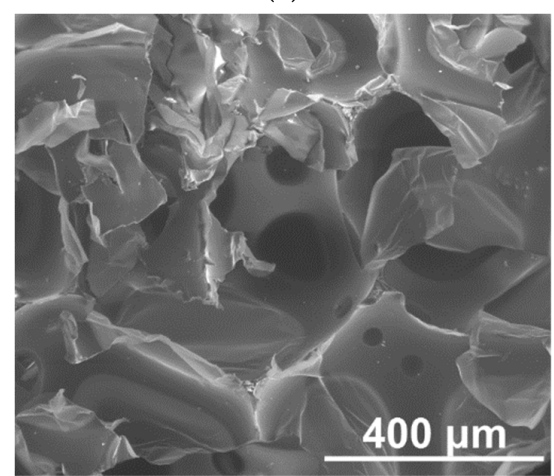

(g)

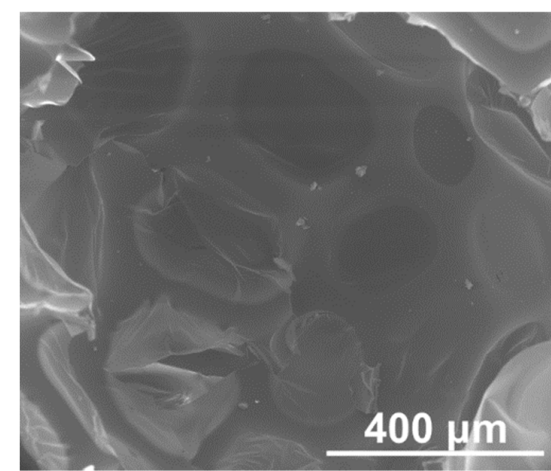

(b)

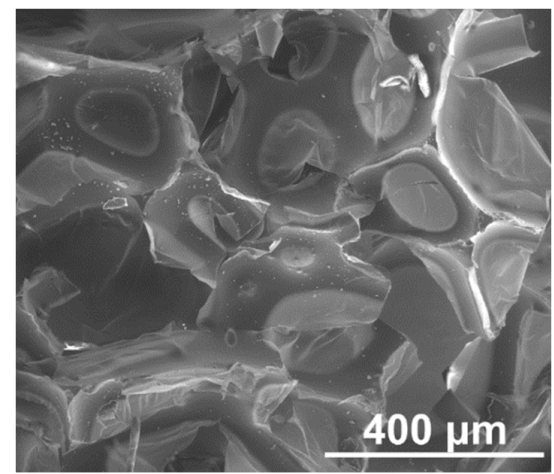

(d)

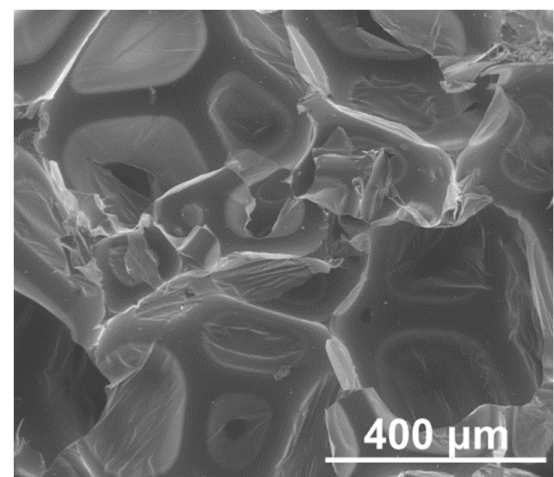

(f)

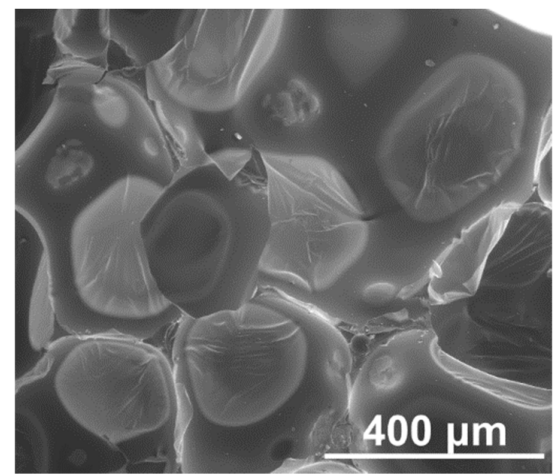

(h)

Figure 4. SEM images of the cross-sections of PUR foams modified with 5 (a,b), 10 (c,d), 15 (e,f), and 20 wt.\% (g,h) of FA (left column) and M (right column). Magnitudes $\times 200$.

Bigger particles of both FA and M impaired the PUR cellular structure, resulting in opening cell walls $[22,40]$. The polyhedron shape of the cells was observed. Fillers were 
evenly dispersed within a polymer matrix and placed between cells (Figure 4). A uniform cellular structure characterized all composite materials. The Feret diameter SD did not exceed $10 \%$ of the average values. Both cellular diameters were comparable, indicating no favorable growth direction. Strut thicknesses were approximately $20 \mu \mathrm{m}$ and were not dependent on the composite composition. Incorporating both types of filler caused a decrease in vertical and horizontal Feret diameters, which suggested that FA particles and $\mathrm{M}$ acted as nucleation sites during the foam formation [22,39]. Moreover, an increase in viscosity of the PUR + FA and PUR + M mixtures and an increasing filler content hindered cell growth during foam formation $[22,41]$.

\subsection{Chemical Structure and Mechanical Properties}

The IR spectra of pristine PUR foam, as received FA, and composite foam material PUR + FA20p were compared (Figure 5, Table 3)), as well as the analogical spectra of PUR + M20p (Figure 6, Table 4). Spectra registered for unmodified PUR foam are shown on the bottom of both plots. Based on XRD analysis, crystalline phases present in the FA sample were mullite and quartz [30]. M were mainly composed of an amorphous phase; mineral phases detected were mullite, corundum and quartz. The similarity in the crystalline composition resulted in comparable IR spectra registered for both FA and M. Bands associated with the silica (quartz), seen on the spectrum of FA (Figure 5; middle plot) and M (Figure 6; middle plot).

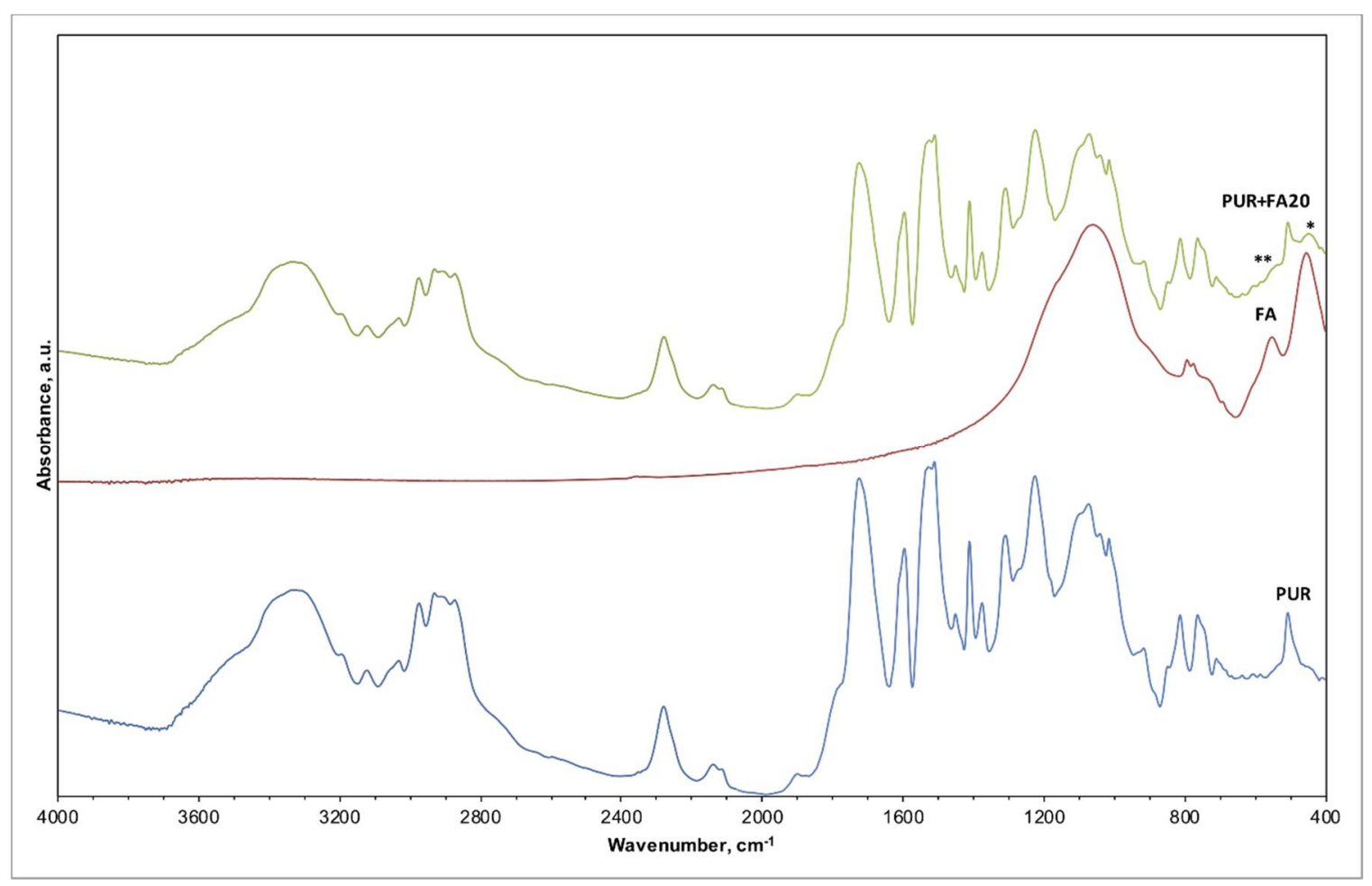

Figure 5. IR spectra of PUR foam, FA, and PUR foam modified with $20 \mathrm{wt} . \%$ of FA (PUR + FA20p). 
Table 3. Absorption bands of the PUR structure [22,42-45].

\begin{tabular}{|c|c|}
\hline Wavenumber, $\mathrm{cm}^{-1}$ & Characteristic Vibration \\
\hline 3330 & Stretching vibration of $\mathrm{N}-\mathrm{H}$ groups \\
\hline 1730 & Stretching vibration of $\mathrm{C}=\mathrm{O}$ bonds \\
\hline $1510-1530$ & Bending vibration of $\mathrm{N}-\mathrm{H}$ groups \\
\hline 1310 & Stretching vibration of $\mathrm{C}-\mathrm{N}$ bonds \\
\hline 1230 & Stretching vibration of $\mathrm{C}-\mathrm{O}$ bonds \\
\hline $2970,2870-2930$ & $\begin{array}{l}\text { Symmetric and asymmetric stretching vibrations of } \mathrm{C}-\mathrm{H} \\
\text { bonds in } \mathrm{CH}_{2} \text { groups in aliphatic chains and } \mathrm{CH}_{3} \text { end groups }\end{array}$ \\
\hline $1450,1410,1340$ & Vibrations of methylene and methyl groups \\
\hline 1090 & $\begin{array}{c}\delta \text { bonds between } \mathrm{C} \text { and } \mathrm{O} \text { (ether bonds; related to the polyol } \\
\text { structure) }\end{array}$ \\
\hline 770-920 & $\begin{array}{l}\text { Skeletal vibrations of } \mathrm{C}-\mathrm{C} \text { bonds and aromatic rings (related } \\
\text { to the isocyanate structure) }\end{array}$ \\
\hline 1600,2280 & Phenyl ring vibration (related to the isocyanate structure) \\
\hline
\end{tabular}

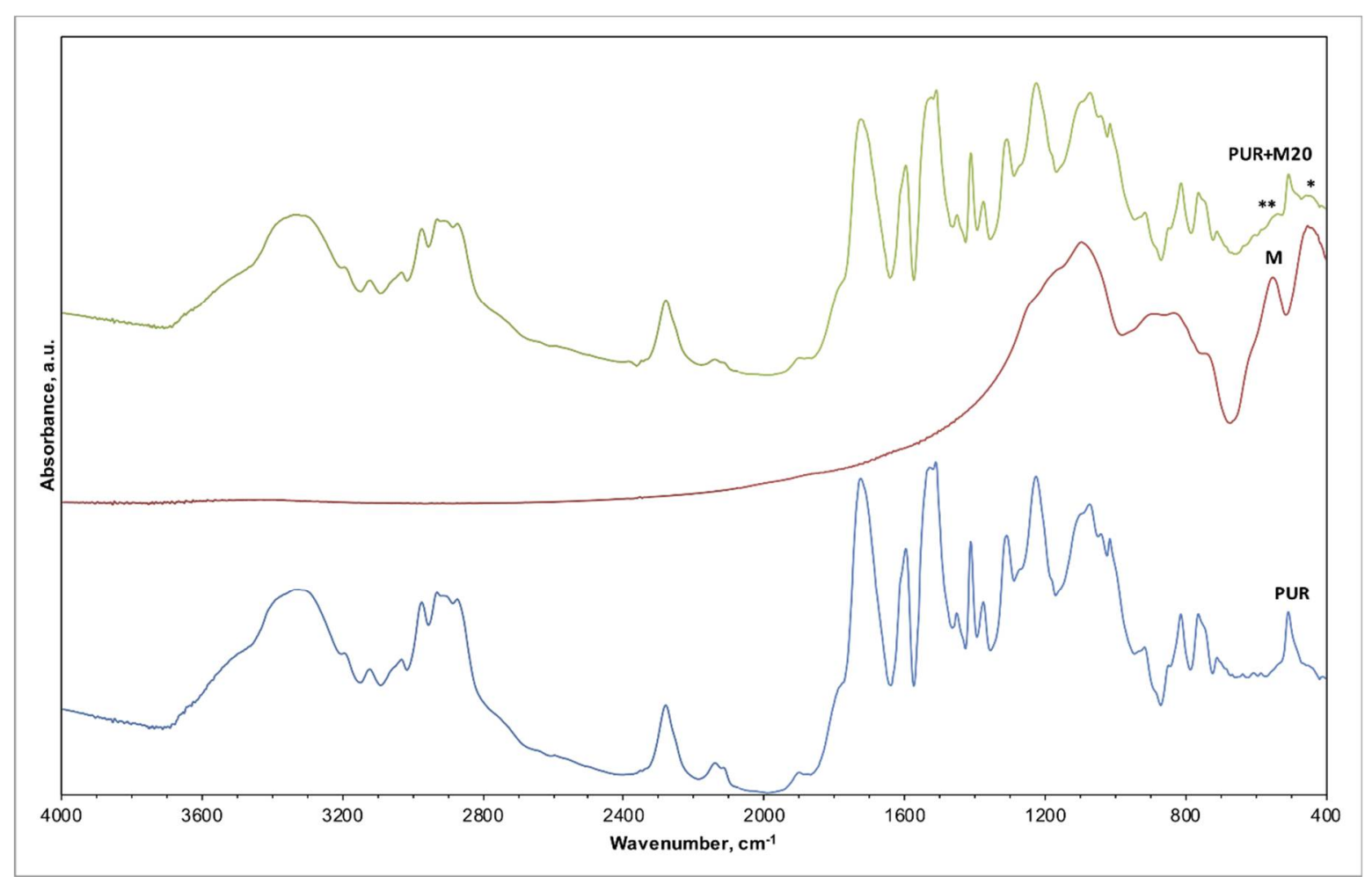

Figure 6. IR spectra of PUR foam, M, and PUR foam modified with $20 \mathrm{wt}$ \% of M (PUR + M20p).

Table 4. Absorption bands of the FA and M structure [46,47].

\begin{tabular}{cc}
\hline Wavenumber, $\mathbf{c m}^{-\mathbf{1}}$ & Characteristic Vibration \\
\hline 1060 & Asymmetric stretching vibration of Si-O(Si) \\
$800-770$ & Symmetric stretching vibration of Si-O-Si \\
460 & Bending vibration of O-Si-O in silicate tetrahedra \\
550 & Al in tetrahedral positions \\
\hline
\end{tabular}

The IR spectrum of PUR + FA20p (Figure 5; top plot) and PUR + M20p (Figure 6; top plot) overlapped with the spectrum of unmodified PUR foam due to the abundant quantity of polymer matrix in the composite. The majority of characteristic bands for both PUR and FA/M occurred in the same wavenumber ranges (Table 3), only slight changes in the spectrum of PUR + FA20p/PUR + M20p suggested the presence of the filler in the polymer 
matrix: $\left(^{*}\right) 550 \mathrm{~cm}^{-1}$ (aluminosilicate); and $(* *) 460 \mathrm{~cm}^{-1}$ (silica). No additional bands belonging to other chemical species were observed, indicating that there is no chemical bonding between polymer and filler.

The values of compressive strength $\left(R_{s}\right)$ and Young's modulus $(E)$, obtained during mechanical testing, are presented in Table 5 . The incorporation of both fillers, up to $20 \mathrm{wt} . \%$, increased both $R_{S}$ and $E$, which suggested the interfacial interactions between polymer matrix and fillers and uniform distribution of fillers within PUR foams. The presence of $\mathrm{M}$ in composite foams resulted in better mechanical characteristics of the samples, which correlated with the conclusions of other research groups [48,49].

Table 5. Mechanical properties of the PUR foams calculated from stress-strain curves.

\begin{tabular}{cc}
\hline Sample Name & Compressive Strength, kPa \\
\hline PUR & $191.6 \pm 14.4$ \\
PUR + FA5p & $210.9 \pm 11.5$ \\
PUR + FA10p & $196.5 \pm 15.9$ \\
PUR + FA15p & $201.3 \pm 27.1$ \\
PUR + FA20p & $243.5 \pm 9.4$ \\
PUR + M5p & $234.5 \pm 11.3$ \\
PUR + M10p & $236.1 \pm 11.3$ \\
PUR + M15p & $235.2 \pm 15.2$ \\
PUR + M20p & $235.7 \pm 25.0$ \\
\hline
\end{tabular}

\subsection{Thermal Properties}

DSC analysis was performed in order to evaluate phase transitions within PUR materials during heating. The glass transition temperatures $\left(\mathrm{T}_{\mathrm{g}}\right)$ and changes in heat capacity $\left(\Delta C_{p}\right)$ are presented in Table 6.

Table 6. Glass transition temperatures and changes in heat capacity, calculated from DSC curves, for the PUR foams.

\begin{tabular}{|c|c|c|c|c|}
\hline Sample Name & $\mathrm{T}_{\mathrm{g}, \mathbf{1}},{ }^{\circ} \mathrm{C}$ & $\begin{array}{c}\Delta \mathrm{C}_{\mathrm{p}, 1} \\
\mathrm{Jg}^{-1} \mathbf{K}^{-1}\end{array}$ & $\mathrm{~T}_{\mathrm{g}, 2},{ }^{\circ} \mathrm{C}$ & $\begin{array}{c}\Delta \mathrm{C}_{\mathrm{p}, 2} \\
\mathrm{~J} \mathrm{~g}^{-1} \mathrm{~K}^{-1}\end{array}$ \\
\hline PUR & 43 & 0.19 & 150 & 0.26 \\
\hline PUR + FA5p & -26 & 0.05 & 160 & 0.22 \\
\hline PUR + FA10p & -22 & 0.06 & 126 & 0.26 \\
\hline PUR + FA15p & -3 & 0.01 & 113 & 0.13 \\
\hline PUR + FA20p & -12 & 0.02 & 103 & 0.25 \\
\hline PUR + M5p & -32 & 0.07 & 131 & 0.31 \\
\hline PUR + M10p & -46 & 0.01 & 128 & 0.24 \\
\hline PUR + M15p & -42 & 0.06 & 128 & 0.35 \\
\hline PUR + M20p & -33 & 0.08 & 147 & 0.15 \\
\hline
\end{tabular}

The $\mathrm{T}_{\mathrm{g}}$ for unmodified PUR foam were approximately 43 and $150{ }^{\circ} \mathrm{C}$. Incorporating both types of filler decreased these parameters, which suggested that they acted as plasticizers and decreased interactions between PUR chains. When the content of fillers increased $\mathrm{T}_{\mathrm{g}, 1}$ was still lower than for pristine PUR foam but higher than parameters calculated for 5 and $10 \mathrm{wt} . \%$ content of the filler. This phenomenon was caused by the lower mobility of polymer chains within the matrix structure resulting from the presence of filler particles. The value of $\Delta \mathrm{C}_{\mathrm{p}, 1}$ for unmodified PUR foam was approximately $0.2 \mathrm{~J} \mathrm{~g}^{-1} \mathrm{~K}^{-1}$ and was the highest value of all samples analyzed, which was related to the greatest mobility of the polymer chains. When fillers were introduced into the PUR structure, changes in heat capacity declined. The values of $\Delta \mathrm{C}_{\mathrm{p}, 2}$ for all materials were comparable (approximately $0.25 \mathrm{~J} \mathrm{~g}^{-1} \mathrm{~K}^{-1}$ ). 
Thermogravimetric analysis (TGA) was carried out under an anaerobic atmosphere in nitrogen to investigate the thermal degradation process of the PUR foam. Figure 7 shows TGA curves registered for the foams with $0,5,10,15$ and $20 \mathrm{wt} . \%$ of fillers.

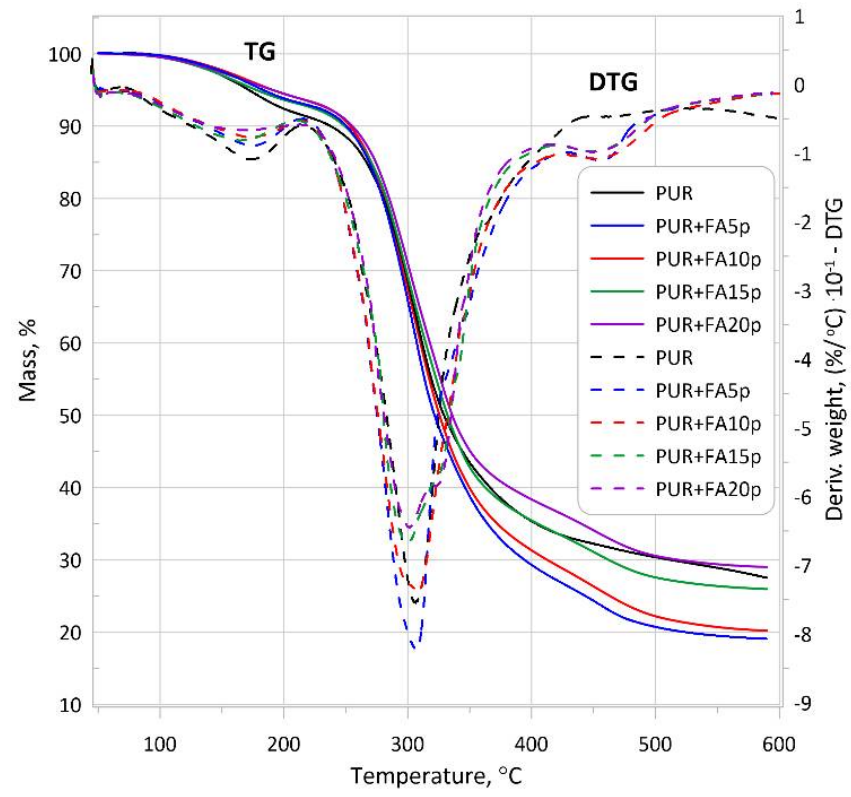

(a)

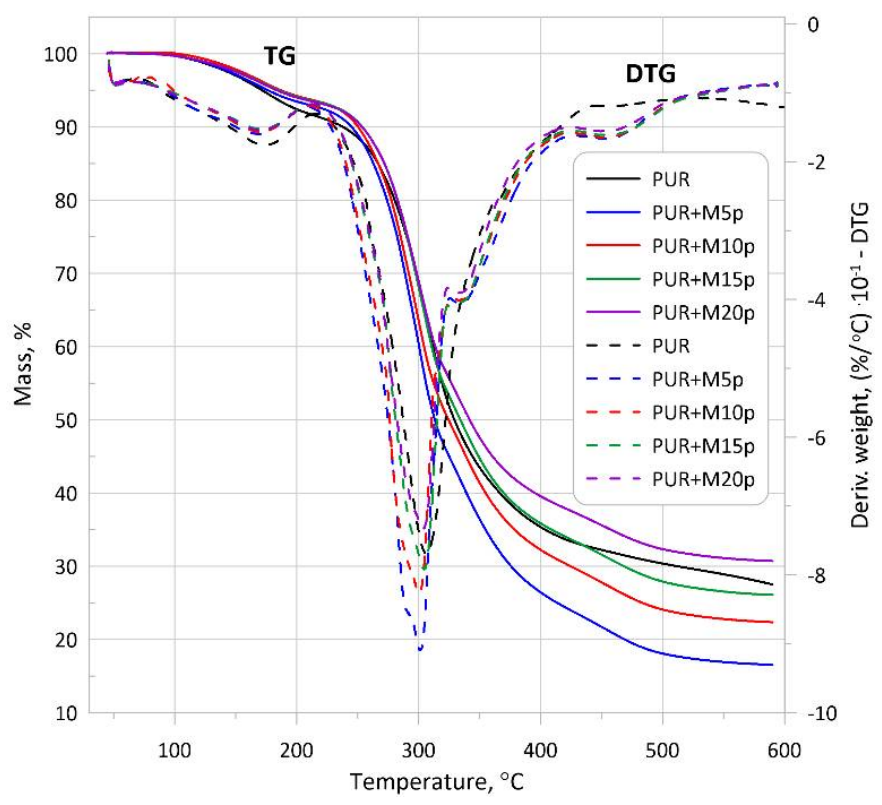

(b)

Figure 7. TGA and DTG curves of unmodified PUR foam and composite materials containing FA (a), and M (b).

The corresponding thermal parameters are marked in Table 7 . These were: $\mathrm{T}_{5 \%}$ - which represented initial degradation temperature corresponding to $5 \%$ weight loss; $\mathrm{T}_{10 \%}$ and $\mathrm{T}_{50 \%}$-temperatures at 10 and $50 \%$ weight loss, respectively; $\mathrm{T}_{1}$ and $\mathrm{T}_{2}$-temperatures with maximum degradation rates in first and second degradation stage, respectively (as the DTG peaks maximum); and $\mathrm{R}_{1}$ and $\mathrm{R}_{2}$-the maximum rate of degradation $\left(\%{ }^{\circ} \mathrm{C}^{-1}\right)$ in first and second degradation stage, respectively.

Table 7. Characteristics of thermal degradation of the PUR foams.

\begin{tabular}{|c|c|c|c|c|c|c|c|c|}
\hline Sample Name & $\mathrm{T}_{5 \%},{ }^{\circ} \mathrm{C}$ & $\mathrm{T}_{10 \%},{ }^{\circ} \mathrm{C}$ & $\mathrm{T}_{\mathbf{5 0} \%},{ }^{\circ} \mathrm{C}$ & $\mathrm{T}_{1},{ }^{\circ} \mathrm{C}$ & $\mathrm{R}_{1}, \%{ }^{\circ} \mathrm{C}^{-1}$ & $\mathrm{~T}_{2},{ }^{\circ} \mathrm{C}$ & $\mathrm{R}_{2}, \%{ }^{\circ} \mathrm{C}^{-1}$ & $\begin{array}{c}\text { Residue at } \\
590{ }^{\circ} \mathrm{C}, \%\end{array}$ \\
\hline PUR & 172 & 238 & 329 & 306 & 0.79 & - & - & 28 \\
\hline PUR + 5FA & 183 & 251 & 322 & 307 & 0.81 & 457 & 0.11 & 19 \\
\hline PUR + 10FA & 191 & 253 & 326 & 308 & 0.73 & 451 & 0.10 & 20 \\
\hline PUR + 15FA & 178 & 249 & 332 & 298 & 0.66 & 447 & 0.09 & 26 \\
\hline PUR + 20FA & 191 & 255 & 336 & 302 & 0.64 & 448 & 0.09 & 29 \\
\hline PUR + 5M & 176 & 245 & 313 & 301 & 0.90 & 451 & 0.09 & 17 \\
\hline PUR + 10M & 187 & 250 & 325 & 301 & 0.81 & 450 & 0.09 & 22 \\
\hline PUR + 15M & 185 & 254 & 334 & 305 & 0.77 & 459 & 0.09 & 26 \\
\hline PUR + 20M & 184 & 254 & 342 & 304 & 0.71 & 449 & 0.08 & 31 \\
\hline
\end{tabular}

The initial mass loss stage $\left(\mathrm{T}_{5 \%}\right)$ is beginning at a temperature range of $170-190{ }^{\circ} \mathrm{C}$. In the case of unmodified PUR foams, the $10 \mathrm{wt} \%$ weight loss occurred at the lowest temperatures $\left(238^{\circ} \mathrm{C}\right.$ ) compared to composite materials (about $250{ }^{\circ} \mathrm{C}$ ). The thermal degradation of all modified PUR foams showed a two-stage degradation. The first step (main degradation process) occurred in the temperature range of $220-450{ }^{\circ} \mathrm{C}$ when hard segments of the PUR structure were destroyed which involved dissociation of the polyol and isocyanate components. In this stage, the highest rate of weight loss $\left(R_{1}\right)$ appeared at temperature $\mathrm{T}_{1}\left(\right.$ about $300^{\circ} \mathrm{C}$ ). The addition of 5 and $10 \mathrm{wt} . \%$ of filler (both FA and M) 
improved the thermal stability of modified foams. Lower temperatures $\left(\mathrm{T}_{1}\right)$ of composites with 15 and $20 \mathrm{wt} . \%$ FA and unmodified PUR can be attributed to earlier chemical decomposition of PUR materials. Addition of filler in excessive amounts (15 and $20 \mathrm{wt} . \%$ of FA) destroy the polymer structure and contribute to earlier degradation. The largest residue after the thermal analysis at $590{ }^{\circ} \mathrm{C}$ occurred in the case of PUR with the addition of $20 \mathrm{wt} . \%$ filler and amounted to approx. 30\% (for unmodified PUR is $28 \%$ ). On the other hand, the smallest amount of residue was in the case of using the filler (FA and M) in the amount of 5\%. The FA occurrence in the content of 15 and $20 \mathrm{wt} . \%$ impaired the cellular structure of PUR and had a slightly negative effect on its thermal resistance. However, the addition of M, even up $20 \mathrm{wt} . \%$, did not adversely affect the thermal stability of the PUR structure. This might be due to the oval shape of the $\mathrm{M}$, which did not damage the PUR cell walls, as shown in Section 2.1 in Figure 2. The second degradation step occurred in the temperature between 420 and $590^{\circ} \mathrm{C}$, and the maximum rate of weight loss $\left(\mathrm{R}_{2}\right)$ occurred at temperature $\mathrm{T}_{2}$ equal to $450{ }^{\circ} \mathrm{C}$. The second degradation step was related to the soft segment decomposition and was slower and much less visible than the degradation of the hard segments.

\section{Conclusions}

The analysis provided in this research article shows that the addition of coal FA up to $10 \mathrm{wt} . \%$ improved the composite's mechanical and thermal properties. The use of FA in the amount greater than $10 \mathrm{wt} . \%$ caused damage to cell walls in a polymer matrix, which caused the worsening of mechanical and thermal properties of polyurethane composites [18]. Coal FA particles, except for a small number of $\mathrm{M}(1-2 \%)$, contained particles of irregular shapes cause damages to the walls of growing polymer cells.

In the case of $\mathrm{M}$ as a filler, no negative influence on the structure of polyurethane cells was observed. This may be due to their oval shape, and therefore there is little possibility of damaging the walls of the growing polyurethane matrix.

The research results on mechanical properties show that incorporating both fillers, up to $10 \mathrm{wt} . \%$, increased both compressive strength and Young's modulus because of the interfacial interactions between polymer matrix and filler particles. The addition of $\mathrm{M}$ to composite foams resulted in better mechanical properties than those obtained for FA-containing foams.

The use of fillers does not change the chemical structure of the polymer because no new bonds appeared in the FTIR spectra of the analyzed materials.

Further studies are necessary in order to obtain the data for other functional properties, e.g., fire properties (heat, smoke, toxic combustion products), water absorption, thermal conductivity, dimensional stability, of FA and M modified rigid polyurethane foams. The extended analysis might be performed for the PUR foams with a more complex construction.

It can be seen that the content of the microspheres varies depending on where the samples are taken. The best solution would be to use a fly ash as a filler with a high content of microspheres, because the separation of microspheres is associated with higher costs. A very good option may be the addition of separated microspheres to fly ash with a small content of microspheres. The authors also carry out the fly ash silanization which make possible to increase the content of microspheres (the article is under preparation).

Author Contributions: Conceptualization, investigation, resources, data curation, writing-original draft preparation, writing-review and editing, visualization, supervision, M.K.; conceptualization, investigation, resources, writing - original draft, writing-review and editing, visualization, supervision, A.M.; writing - review and editing, B.Z.-K.; formal analysis, writing-review and editing, K.K.-C.; investigation, K.P.; investigation, P.S.; investigation, A.B.; investigation, M.Z.; investigation, W.J. All authors have read and agreed to the published version of the manuscript.

Funding: The research was funded by the National Science Centre, Poland under project No 2020/04/X/ST8/00314 [MINIATURA 4]. The work was realized as a part of fundamental research co-financed by the Ministry of Science and Higher Education, Poland [grant AGH-UST 16.16.110.663]. 
Institutional Review Board Statement: Not applicable.

Informed Consent Statement: Not applicable.

Conflicts of Interest: The authors declare no conflict of interest.

\section{References}

1. Wang, S.; Yang, X.; Li, Z.; Xu, X.; Liu, H.; Wang, D.; Min, H.; Shang, S. Novel eco-friendly maleopimaric acid based polysiloxane flame retardant and application in rigid polyurethane foam. Compos. Sci. Technol. 2020, 198, 108272. [CrossRef]

2. Zhou, Y.; Bu, R.; Yi, L.; Sun, J. Heat transfer mechanism of concurrent flame spread over rigid polyurethane foam: Effect of ambient pressure and inclined angle. Int. J. Therm. Sci. 2020, 155, 106403. [CrossRef]

3. Szycher, M. Szycher's Handbook of Polyurethanes; CRC Press: Boca Raton, FL, USA, 1999.

4. Stanzione, M.; Russo, V.; Oliviero, M.; Verdolotti, L.; Sorrentino, A.; Di Serio, M.; Tesser, R.; Iannace, S.; Lavorgna, M. Synthesis and characterization of sustainable polyurethane foams based on polyhydroxyls with different terminal groups. Polymer 2018, 149, 134-145. [CrossRef]

5. Pagacz, J.; Hebda, E.; Michałowski, S.; Ozimek, J.; Sternik, D.; Pielichowski, K. Polyurethane foams chemically reinforced with POSS-Thermal degradation studies. Thermochim. Acta 2016, 642, 95-104. [CrossRef]

6. Zhang, L.; Zhang, M.; Zhou, Y.; Hu, L. The study of mechanical behavior and flame retardancy of castor oil phosphate-based rigid polyurethane foam composites containing expanded graphite and triethyl phosphate. Polym. Degrad. Stab. 2013, 98, $2784-2794$. [CrossRef]

7. Członka, S.; Strakowska, A.; Strzelec, K.; Kairyte, A.; Vaitkus, S. Composites of rigid polyurethane foams and silica powder filler enhanced with ionic liquid. Polym. Test. 2019, 75, 12-25. [CrossRef]

8. Zatorski, W.; Brzozowski, Z.K.; Kolbrecki, A. New developments in chemical modification of fire-safe rigid polyurethane foams. Polym. Degrad. Stab. 2008, 93, 2071-2076. [CrossRef]

9. Research, I. Global Rigid Polyurethane Foam (RPUF) Sales Market Report 2021. Available online: https: / / www.industryresearch. biz/global-rigid-polyurethane-foam-rpuf-sales-market-17401488 (accessed on 19 March 2021).

10. Członka, S.; Sienkiewicz, N.; Strakowska, A.; Strzelec, K. Keratin feathers as a filler for rigid polyurethane foams on the basis of soybean oil polyol. Polym. Test. 2018, 72, 32-45. [CrossRef]

11. Qian, L.; Li, L.; Chen, Y.; Xu, B.; Qiu, Y. Quickly self-extinguishing flame retardant behavior of rigid polyurethane foams linked with phosphaphenanthrene groups. Compos. Part B Eng. 2019, 175, 107186. [CrossRef]

12. Zieleniewska, M.; Leszczyński, M.K.; Szczepkowski, L.; Bryśkiewicz, A.; Krzyżowska, M.; Bień, K.; Ryszkowska, J. Development and applicational evaluation of the rigid polyurethane foam composites with egg shell waste. Polym. Degrad. Stab. 2016, 132, 78-86. [CrossRef]

13. Baek, S.H.; Kim, J.H. Polyurethane composite foams including silicone-acrylic particles for enhanced sound absorption via increased damping and frictions of sound waves. Compos. Sci. Technol. 2020, 198, 108325. [CrossRef]

14. Leszczyńska, M.; Ryszkowska, J.; Szczepkowski, L.; Kurańska, M.; Prociak, A.; Leszczyński, M.K.; Gloc, M.; Antos-Bielska, M.; Mizera, K. Cooperative effect of rapeseed oil-based polyol and egg shells on the structure and properties of rigid polyurethane foams. Polym. Test. 2020, 90, 106696. [CrossRef]

15. Zhang, X.; Kim, Y.; Eberhardt, T.L.; Shmulsky, R. Lab-scale structural insulated panels with lignin-incorporated rigid polyurethane foams as core. Ind. Crop. Prod. 2019, 132, 292-300. [CrossRef]

16. Da Silva, V.R.; Mosiewicki, M.A.; Yoshida, M.I.; Da Silva, M.C.; Stefani, P.M.; Marcovich, N.E. Polyurethane foams based on modified tung oil and reinforced with rice husk ash I: Synthesis and physical chemical characterization. Polym. Test. 2013, 32, 438-445. [CrossRef]

17. Da Silva, V.R.; Mosiewicki, M.A.; Yoshida, M.I.; Da Silva, M.C.; Stefani, P.M.; Marcovich, N.E. Polyurethane foams based on modified tung oil and reinforced with rice husk ash II: Mechanical characterization. Polym. Test. 2013, 32, 665-672. [CrossRef]

18. Kuźnia, M.; Magiera, A.; Pielichowska, K.; Ziąbka, M.; Benko, A.; Szatkowski, P.; Jerzak, W. Fluidized bed combustion fly ash as filler in composite polyurethane materials. Waste Manag. 2019, 92, 115-123. [CrossRef]

19. Choe, H.; Lee, J.H.; Kim, J.H. Polyurethane composite foams including $\mathrm{CaCO}_{3}$ fillers for enhanced sound absorption and compression properties. Compos. Sci. Technol. 2020, 194, 108153. [CrossRef]

20. Chindaprasirt, P.; Rattanasak, U. Utilization of blended fluidized bed combustion (FBC) ash and pulverized coal combustion (PCC) fly ash in geopolymer. Waste Manag. 2010, 30, 667-672. [CrossRef]

21. Chindaprasirt, P.; Jenjirapanya, S.; Rattanasak, U. Characterizations of FBC/PCC fly ash geopolymeric composites. Constr. Build. Mater. 2014, 66, 72-78. [CrossRef]

22. Anthony, E.; Berry, E.; Blondin, J.; Bulewicz, E.; Burwell, S. Advanced ash management technologies for CFBC ash. Waste Manag. 2003, 23, 503-516. [CrossRef]

23. Hejna, A.; Kopczyńska, M.; Kozłowska, U.; Klein, M.; Kosmela, P.; Piszczyk, Ł. Foamed polyurethane composites with different types of ash-morphological, mechanical and thermal behavior assessments. Cell. Polym. 2016, 35, 287-308. [CrossRef]

24. Sroka, J.; Rybak, A.; Sekuła, R.; Sitarz, M. An Investigation into the Influence of Filler Silanization Conditions on Mechanical and Thermal Parameters of Epoxy Resin-Fly Ash Composites. J. Polym. Environ. 2016, 24, 298-308. [CrossRef] 
25. Sroka, J.; Rybak, A.; Sekuła, R.; Filipczak, P.; Kozanecki, M.; Sitarz, M. Two-Step Procedure of Fly Ash Modification as an Alternative Method for Creation of Functional Composite. J. Polym. Environ. 2017, 25, 1342-1347. [CrossRef]

26. Porabka, A.; Jurkowski, K.; Laska, J. Fly ash used as a reinforcing and flame- retardant filler in low-density polyethylene. Polimery 2015, 60, 251-257. [CrossRef]

27. Liu, H.; Sun, Q.; Wang, B.; Wang, P.; Zou, J. Morphology and Composition of Microspheres in Fly Ash from the Luohuang Power Plant, Chongqing, Southwestern China. Minerals 2016, 6, 30. [CrossRef]

28. Nugteren, H.W. Coal fly ash: From waste to industrial product. Part. Part. Syst. Charact. 2007, 24, 49-55. [CrossRef]

29. Drozhzhin, V.; Shpirt, M.Y.; Danilin, L.; Kuvaev, M.; Pikulin, I.; Potemkin, G.; Redyushev, S. Formation processes and main properties of hollow aluminosilicate microspheres in fly ash from thermal power stations. Solid Fuel Chem. 2008, 42, 107-119. [CrossRef]

30. Grishin, N.; Belogurova, O.; Belyaevskii, A.; Osipov, Y.P.; Kalinnikov, V. High- temperature heat-insulating materials based on hollow aluminosilicate microspheres from the ash dump of the apatity thermal power plant. Refract. Ind. Ceram. 2000, 41, 50-55. [CrossRef]

31. Kuźnia, M.; Magiera, A.; Jerzak, W.; Ziąbka, M.; Lach, R. Study on chemical composition of fly ash ram fluidized-bed and conventional coal combustion. Przem. Chem. 2017, 96, 1699-1703. [CrossRef]

32. Magiera, A.; Kuźnia, M.; Jerzak, W.; Ziąbka, M.; Lach, R.; Handke, B. Microspheres as potential fillers in composite polymeric materials. E3S Web Conf. 2019, 108, 02009. [CrossRef]

33. Ma, X.F.; Yu, J.G.; Wang, N. Fly ash-reinforced thermoplastic starch composites. Carbohydr. Polym. 2007, 67, 32-39. [CrossRef]

34. Ramesh, A.; Ramu, K.; Ahmed Ali Baig, M.; Dinesh Guptha, E. Influence of fly ash nano filler on the tensile and flexural properties of novel hybrid epoxy nano-composites. Mater. Today Proc. 2020, 27, 1252-1257. [CrossRef]

35. Tiwari, S.; Gehlot, C.L.; Srivastava, D. Synergistic influence of $\mathrm{CaCO} 3$ nanoparticle on the mechanical and thermal of fly ash reinforced epoxy polymer composites. Mater. Today Proc. 2021, 43, 3375-3385. [CrossRef]

36. Girge, A.; Goel, V.; Gupta, G.; Fuloria, D.; Ranjan Pati, P.; Sharma, A.; Kumar Mishra, V. Industrial waste filled polymer composites-A review. Mater. Today Proc. 2021, 47, 2852-2863. [CrossRef]

37. Rozhina, E.; Ishmukhametov, I.; Nigamatzyanova, L.; Akhatova, F.; Batasheva, S.; Taskaev, S.; Montes, C.; Lvov, Y.; Fakhrullin, R. Comparative Toxicity of Fly Ash: An In Vitro Study. Molecules 2021, 26, 1926. [CrossRef]

38. Prociak, A.; Kurańska, M.; Malewska, E. Porous polyurethane plastics synthetized using bio-polyols from renewable raw materials. Polimery 2017, 62, 353-363. [CrossRef]

39. Prociak, A. Heat-insulating properties of rigid polyurethane foams synthesized with use of vegetable oils-based polyols. Polimery 2008, 53, 195-200. [CrossRef]

40. Usta, N. Investigation of fire behavior of rigid polyurethane foams containing fly ash and intumescent flame retardant by using a cone calorimeter. J. Appl. Polym. Sci. 2012, 124, 3372-3382. [CrossRef]

41. Tarakcilar, A.R. The effects of intumescent flame retardant including ammonium polyphosphate/pentaerythritol and fly ash fillers on the physicomechanical properties of rigid polyurethane foams. J. Appl. Polym. Sci. 2011, 120, 2095-2102. [CrossRef]

42. Madaleno, L.; Pyrz, R.; Crosky, A.; Jensen, L.R.; Rauhe, J.C.M.; Dolomanova, V.; de Barros, A.M.M.V.; Pinto, J.J.C.; Norman, J. Processing and characterization of polyurethane nanocomposite foam reinforced with montmorillonite-carbon nanotube hybrids. Compos. Part A Appl. Sci. Manuf. 2013, 44,1-7. [CrossRef]

43. Asefnejad, A.; Khorasani, M.T.; Behnamghader, A.; Farsadzadeh, B.; Bonakdar, S. Manufacturing of biodegradable polyurethane scaffolds based on polycaprolactone using a phase separation method: Physical properties and in vitro assay. Int. J. Nanomed. 2011, 6, 2375-2384. [CrossRef]

44. Trovati, G.; Sanches, E.A.; Neto, S.C.; Mascarenhas, Y.P.; Chierice, G.O. Characterization of polyurethane resins by FTIR, TGA and XRD. J. Appl. Polym. Sci. 2010, 115, 263-268. [CrossRef]

45. Gujral, P.; Varshney, S.; Dhawan, S. Designing of Multiphase Fly Ash/MWCNT/PU Composite Sheet Against Electromagnetic Environmental Pollution. J. Electron. Mater. 2016, 45, 3142-3148. [CrossRef]

46. Hejna, A.; Kosmela, P.; Mikicka, M.; Danowska, M.; Piszczyk, Ł. Modification of microporous polyurethane elastomers with different types of ash-morphological, mechanical, and thermal studies. Polym. Compos. 2016, 37, 881-889. [CrossRef]

47. Mozgawa, W.; Król, M.; Dyczek, J.; Deja, J. Investigation of the coal fly ashes using IR spectroscopy. Spectrochim. Acta Part A Mol. Biomol. Spectrosc. 2014, 132, 889-894. [CrossRef]

48. Fauzi, A.; Nuruddin, M.F.; Malkawi, A.B.; Abdullah, M.M.A.B. Study of fly ash characterization as a cementitious material. Procedia Eng. 2016, 148, 487-493. [CrossRef]

49. Paciorek-Sadowska, J.; Czupryński, B.; Borowicz, M.; Liszkowska, J. Rigid polyurethane-polyisocyanurate foams modified with grain fraction of fly ashes. J. Cell. Plast. 2020, 56, 53-72. [CrossRef] 